\title{
Knowledge and Ideology in the Sociology of Education
}

GERALD BERNBAUM

Professor in the School of Education

University of Leicester 
C) British Sociological Association 1977
Reprint of the original edition 1977

All rights reserved. No part of this publication may be reproduced or transmitted, in any form or by any means, without permission.

First published 1977 by

THE MACMILLAN PRESS LTD

London and Basingstoke Associated companies in New York Dublin Melbourne Johannesburg and Madras

SBN 333157621

This book is sold subject to the standard conditions of the Net Book Agreement.

The paperback edition of this book is sold subject to the condition that it shall not, by way of trade or otherwise, be lent, re-sold, hired out, or otherwise circulated without the publisher's prior consent in any form of binding or cover other than that in which it is published and without a similar condition including this condition being imposed on the subsequent purchaser. 


\section{STUDIES IN SOGIOLOGY}

General Editor: ANtнолy Giddens

Editorial Advisers: T. B. BotTomore, DAvid Lockwood and ERNEST GeLLNER

\section{Published}

THE SOCIOLOGY OF SOCIAL MOVEMENTS

J. A. Banks

KNOWLEDGE AND IDEOLOGY IN THE SOGIOLOGY OF EDUGATION

Gerald Bernbaum

MARXIST SOCIOLOGY

Tom Bottomore

POLITICS AND SOGIOLOGY IN THE THOUGHT OF MAX WEBER

Anthony Giddens

THE USE OF OFFICIAL STATISTICS IN SOGIOLOGY

Barry Hindess

STRIKES AND INDUSTRIAL CONFLIGT: BRITAIN AND SCANDINAVIA

Geoffrey K. Ingham

PROFESSIONS AND POWER

Terence J. Johnson

POWER: A RADICAL VIEW

Steven Lukes

THE ORGANISATION OF GRIME

Mary McIntosh

CONSCIOUSNESS AND AGTION AMONG THE WESTERN WORKING CLASS Michael Mann

THE SOGIAL PROGESS OF INNOVATION: A STUDY IN THE SOGIOLOGY OF SGIENCE

M. J. Mulkay

Forthcoming

THE DEVELOPMENT OF THE SOGIOLOGY OF RNOWLEDGE

Steven Lukes

GLASS THEORY AND THE DIVISION OF LABOUR

Gavin Mackenzie 


\section{STUDIES IN SOGIOLOGY}

This series, prepared under the auspices of the British Sociological Association, is designed to provide short but comprehensive and scholarly treatments of key problem-areas in sociology. The books do not offer summary accounts of the current state of research in various fields, but seek rather to analyse matters which are the subject of controversy or debate. The series is designed to cover a broad range of topics, falling into three categories: (1) abstract problems of social theory and social philosophy; (2) interpretative questions posed by the writings of leading social theorists; (3) issues in empirical sociology. In addition, the series will carry translations of important writings in sociology which have not previously been available in English. Each book makes a substantive contribution to its particular topic, while at the same time giving the reader an indication of the main problems at issue; each carries an annotated bibliography, comprising a critical survey of relevant further literature.

University of Cambridge

Anthony Gidden 


\section{GONTENTS}

$\begin{array}{ll}\text { Preface } & 7\end{array}$

1 Introduction: The 'New' and the 'Old' Sociology of Education

2 An Account of the Sociology of Education: I

3 An Account of the Sociology of Education: II 43

4 Critique and Conclusion $\quad 55$

Further Reading 71

References $\quad 73$ 


\section{PREFACE}

THIS short study is about the sociology of education. In particular, I have tried to set the recent developments within the subject in the context of other changes, changes in sociological theory, educational practice and educational ideologies. Though, at times, I am critical of some of the new ideas which are now available, there is a very real sense in which the present study could not have been written without the insights and perspectives which are represented by the 'new directions in the sociology of education.'

I am therefore grateful to all who have been involved in the attempt to change the sociology of education. Also (though I must not assume that they do not wish to change the sociology of education), I am grateful to Tom Whiteside and Sara Delamont for reading and commenting upon a draft of this study, and to Tony Giddens for his very helpful advice. Needless to say I accept full responsibility for the arguments developed, and the faults, particularly, remain obstinately my own.

G.B. 